\title{
Pembuatan Formulasi Ektrak Kulit Batang Calophyllum soulattri dan Aktivitas Residu terhadap Larva Crocidolomia pavonana
}

\author{
EDY SYAHPUTRA ${ }^{1)}$ DAN DJOKO PRIJONO ${ }^{2)}$ \\ ${ }^{1)}$ Fakultas Pertanian, Universitas Tanjungpura Pontianak. \\ ${ }^{2)}$ Fakultas Pertanian, Institut Pertanian Bogor
}

(diterima November 2007, disetujui Februari 2008)

\begin{abstract}
Formulation of Calophyllum soulattri Bark Extract and Residual Activity against Crocidolomia pavonana Larvae. One option to lessen the problems arising from the use of synthetic insecticides is to exploit plants that have insecticidal activities, such as species of Calophyllum (Clusiaceae). The study has been conducted to prepare insecticidal formulation from $C$. soulattri bark extract and to evaluate their residual activity against $C$. pavonana. Formulation prepared by using emulsifier, solvent, and sticking agent. Colour, acidity and emulsion stability were recorded as physic-chemical character of formulation. The result showed that the formulation of $C$. soulattri bark extract was stable, and their $\mathrm{pH}$ was normal. Bioassay of residual activity was done using leaf-residual method. Formulation of bark extract of $66 \mathrm{EC}$ sprayed in suspension concentration of $1 \%$ on potted broccoli plant had residual activity around $70.7 \%-72 \%$ with range of half-lives of 9.4-9.6 days.
\end{abstract}

KEY WORDS: Calophyllum soulattri, formulation, half-lives, residual activity

\section{PENDAHULUAN}

Salah satu kelompok tumbuhan yang memiliki aktivitas insektisida ialah tumbuhan famili Clusiaceae (Jacobson 2003), salah satunya spesies dari genus Calophyllum, yaitu $C$. soulattri. Tumbuhan ini banyak terdapat di hutan-hutan tropik Indonesia. Informasi tentang aktivitas C. soulattri sebagai insektisida masih terbatas. Sediaan kulit batang $C$. soulattri memiliki aktivitas insektisida yang kuat terhadap larva Crocidolomia pavonana. Sediaan tersebut juga dapat menghambat aktivitas makan dan menghambat pertumbuhan larva serta menekan reproduksi imago $C$. pavonana (Syahputra et al. 2007). Dengan memperhatikan bioaktivitas yang dimiliki dapat dikatakan sediaan kulit batang $C$. soulattri berpotensi untuk dikembangkan sebagai salah satu sumber insektisida botani.

Setelah potensi insektisida suatu bahan tanaman diketahui, untuk aplikasinya di lapangan diperlukan 
sediaan atau formulasi. Bila sumber insektisida mudah diperoleh oleh petani, maka petani dapat memanfaatkannya langsung dengan membuat sediaan ekstrak air. Permasalahan akan timbul bila sumber ekstrak berada jauh dari sekitar petani. Karenanya penggunaan sediaan yang disiapkan dengan pelarut organik menjadi salah satu alternatif. Untuk memudahkan aplikasi, sediaan organik tersebut perlu disiapkan dalam bentuk formulasi tertentu.

Formulasi insektisida yang umum ditemukan dipasaran adalah formulasi emulsifiable concentrate (EC). Formulasi EC merupakan insektisida berbentuk cairan pekat yang dapat dicampur dengan air dan akan membentuk emulsi (Foy \& Pritchard 1996). Hingga kini belum dilaporkan penyiapan formulasi sediaan $C$. soulattri. Melalui penelitian ini akan disiapkan formulasi EC insektisida botani dari ekstrak kulit batang $C$. soulattri. Formulasi yang dihasilkan diharapkan efektif, stabil dan aman di lapangan.

Penelitian mengenai sifat insektisida $C$. soulattri masih terbatas pada pengujian di laboratorium. Hasil pengujian di laboratorium tidak dapat langsung ditransfer ke lapangan karena berbagai faktor biotik dan abiotik dapat mempengaruhi kinerja insektisida di lapangan. Pengaruh faktor tersebut dan faktor-faktor lain dapat menurunkan aktivitas residu insektisida secara keseluruhan. Berdasarkan uraian di atas dapat dikemukakan bahwa kestabilan setiap insektisida yang akan digunakan perlu diketahui terlebih dahulu. Penelitian ini dilakukan untuk mempelajari aktivitas residu sediaan ekstrak kulit batang $C$. soulattri.

\section{BAHAN DAN METODE}

Penelitian dilaksanakan di Laboratorium Fisiologi dan Toksikologi (Fistok), Jurusan Hama dan Penyakit Tumbuhan (HPT), Fakultas Pertanian, Institut Pertanian Bogor. Penelitian dilaksanakan sejak Pebruari 2003 hingga Maret 2004.

\section{Tumbuhan Sumber Ekstrak}

Bahan tumbuhan uji yang digunakan ialah kulit batang $C$. soulattri. Bahan tanaman diperoleh dari Kecamatan Teluk Melano, Kabupaten Ketapang, Provinsi Kalimantan Barat. Kulit batang yang digunakan terlebih dahulu diblender hingga menjadi serbuk dan diayak menggunakan pengayak kasa berjalinan $1 \mathrm{~mm}$. Serbuk ayakan ditimbang untuk keperluan ekstraksi. Kadar air bahan yang digunakan ialah $13,4 \%$.

\section{Ekstraksi}

Ekstraksi bahan tanaman dilakukan seperti cara yang diuraikan Syahputra et al. (2007). Serbuk ayakan kulit batang yang telah ditimbang diekstraksi dengan pelarut metanol 
dengan perbandingan bobot bahan dan pelarut 1:10. Bahan direndam dalam metanol selama 3 x 24 jam, selanjutnya disaring menggunakan corong yang dialasi kertas saring. Pembilasan dilakukan sebanyak tiga kali. Hasil penyaringan diuapkan dengan rotary evaporator pada suhu $55-60{ }^{\circ} \mathrm{C}$ dan penghampaan pada tekanan $580-600$ $\mathrm{mmHg}$ sehingga diperoleh ekstrak metanol.

\section{Tumbuhan Pakan}

Benih brokoli ( $\mathrm{F}_{1}$ Hybrid Broccoli pilgrim) disemai pada tanah steril dalam wadah nampan plastik $(35 \mathrm{~cm} \mathrm{x}$ $26 \mathrm{~cm}$ ). Wadah semaian diletakkan di serambi Laboratorium Fistok. Setelah 3 minggu, bibit dipindah ke polybag isi 5 liter yang berisi campuran tanah dan pupuk kandang $(3: 1)$. Tanah dipupuk dengan NPK sesuai dosis yang dianjurkan, dan selanjutnya tanaman brokoli dirawat sehingga pada saat perlakuan tersedia 39 tanaman yang pertumbuhannya cukup seragam. Tanaman yang digunakan berumur sekitar 7-8 minggu (setelah pemindahan ke polybag). Menjelang percobaan, tanaman brokoli dipindahkan ke ruangan terbuka tanpa peneduh. Sebelum penyemprotan, tanaman dirampingkan sehingga pada setiap tanaman hanya tersisa lima daun yang telah berkembang sempurna. Tanaman perlakuan dan kontrol masing-masing dibagi menjadi tiga ulangan. Jumlah tanaman untuk tiap perlakuan adalah dua tanaman.

\section{Metode Pembuatan Formulasi}

Besarnya kandungan ekstrak dalam formulasi ialah $3 \times \mathrm{LC}_{99}$ berdasarkan hasil uji mortalitas di laboratorium. Penggandaan $\mathrm{LC}_{99}$ dilakukan untuk mempertimbangkan kemungkinan terjadinya penguraian senyawa aktif yang terkandung dalam sediaan uji oleh faktor lingkungan. Konsentrasi formulasi yang digunakan adalah 1\% (5 kali konsentrasi formulasi insektisida sintetik $=10 \mathrm{ml} / \mathrm{L}$ ) dan volume semprot yang digunakan adalah $500 \mathrm{ml}$ untuk 39 tanaman. Dengan nilai LC $_{99}$ ekstrak metanol sebesar 0,22\% maka akan diperoleh formulasi ekstrak metanol $66 \operatorname{EC}(0,22 \times 3=0,66=$ $66 \%$ ). Untuk membuat volume semprot $500 \mathrm{ml}$ diperlukan bahan formulasi $5 \mathrm{ml}$ (untuk mendapatkan konsentrasi formulasi $1 \%=5 \mathrm{ml} / 500$ ml). Dengan demikian untuk pembuatan formulasi ekstrak $66 \mathrm{EC}$ dilakukan dengan mencampur 66\% ekstrak metanol (3,3 g), pengemulsi alkilgliserolftalat 7,7\% ( $\mathrm{v} / \mathrm{v}$ ) (Latron 0,5 $\mathrm{ml}$ ), perekat alkilarilpoliglikol eter 3\% $(\mathrm{v} / \mathrm{v}$ ) (Agristik 0,5 ml) dan metanol hingga volume $5 \mathrm{ml}$. Campuran bahan tersebut dikocok hingga tercampur merata. Untuk perlakuan ekstrak yang mengandung tabir surya asam $p$ aminobenzoat $(0,2 \%)$ perhitungannya disesuaikan. Campuran bahan dikocok hingga tercampur merata. Formulasi EC yang diperoleh disimpan dalam lemari es $\left(4{ }^{\circ} \mathrm{C}\right)$ hingga saat digunakan. 


\section{Metode Pengujian Aktivitas Residu}

Saat akan digunakan, formulasi diencerkan dengan cara mencampur setiap formulasi secara terpisah dengan aquades dalam labu takar $500 \mathrm{ml}$. Dalam percobaan ini digunakan dua perlakuan kontrol di antaranya (1) aquades yang mengandung pengemulsi alkil gliserolftalat $0,077 \%$, perekat alkilarilpoliglikol eter $0,03 \%$, dan metanol $0,14 \%$, (2) aquades yang mengandung pengemulsi alkilgliserolftalat $\quad 0,077 \%$, perekat alkilarilpoliglikol eter $0,03 \%$, metanol $0,14 \%$, dan asam $p$-aminobenzoat $0,2 \%$, Sebagai kontrol positif digunakan insektisida alami (Bacillus thuringiensis) dan insektisida sintetik (profenofos; golongan organofosfat). Konsentrasi formulasi insektisida alami dan sintetik yang digunakan sesuai dengan anjuran median yang tertulis pada label kemasan. Secara keseluruhan perlakuan dan kontrol yang diuji pada percobaan ini ditunjukkan pada Tabel 1.

Pengujian dilakukan dengan metode penyemprotan pada tanaman brokoli dalam polybag di ruang terbuka tanpa peneduh. Saat perlakuan daun tanaman diseragamkan menjadi lima daun per tanaman. Penyemprotan formulasi dan kontrol dilakukan dengan hand sprayer. Sebagai perlakuan daun brokoli diambil pada 0 , $1,2,3,5.7,10$, dan 14 hari setelah penyemprotan sebagai pakan. Daun diletakkan dalam wadah plastik (11 cm $x \quad 9,5 \mathrm{~cm} \times 4,5 \mathrm{~cm}$ ), selanjutnya dimasukkan 30 larva instar II $C$. pavonana. Setelah 48 jam, daun perlakuan diganti dengan daun segar tanpa perlakuan hingga larva mencapai instar IV.

\section{Pengamatan Formulasi}

Sifat fisikokimia yang diamati adalah warna, kestabilan emulsi dan pH setelah diencerkan, Kestabilan diuji pada suhu ruang dan suhu rendah. Pada suhu ruang pengujian dilaksanakan di laboratorium. Pengamatan kestabilan dilakukan pada 2 jam pertama setelah formulasi diencerkan. Pada suhu rendah, pengujian dilakukan di dalam inkubator suhu $10{ }^{\circ} \mathrm{C}$.

Tabel 1. Susunan perlakuan formulasi pada pengujian aktivitas residu sediaan kulit batang C. soulattri

\begin{tabular}{ll}
\hline \hline \multicolumn{1}{c}{ Perlakuan } & \multicolumn{1}{c}{ Bahan formulasi } \\
\hline Kontrol & Aquades, pengemulsi, perekat, dan metanol \\
& Aquades, pengemulsi, perekat, metanol, dan $p$-aminobenzoat \\
Formulasi & Ekstrak EC, pengemulsi, perekat dan metanol \\
& Ekstrak EC, pengemulsi, perekat, metanol dan $p$-aminobenzoat \\
Alami & Bacillus thuringiensis \\
Sintetik & Profenofos \\
\hline
\end{tabular}


Pengamatan kestabilan dilakukan pada satu jam pertama setelah formulasi diencerkan (CIPAC 1980). Pengamatan dilakukan dengan melihat terbentuknya endapan pada bagian lapisan dasar emulsi. Banyaknya endapan diukur dengan menghitung volume (ml) endapan yang terbentuk. Pengukuran $\mathrm{pH}$ kedua formulasi dilakukan menggunakan $\mathrm{pH}$ meter.

\section{Pengamatan Aktivitas Residu}

Peubah yang diamati adalah mortalitas larva C. pavonana instar II dan instar II+III. Pada percobaan ini juga dilakukan pengamatan gejala fitotoksisitas pada tanaman brokoli.

\section{Analisis Data}

Persentase mortalitas larva setiap perlakuan terhadap waktu dipetakan. Waktu paruh dihitung berdasarkan persamaan regresi hubungan antara waktu dan mortalitas dengan menggunakan rumus $\mathrm{WP}=[\sqrt{ }(50+$
0,5) $b+a)$ ] (Immaraju et al. 1994). WP adalah waktu paruh, $b$ adalah kemiringan regresi, dan a adalah intersep.

Sebagai data pendukung digunakan data radiasi surya dan curah hujan dari Badan Meteorologi dan Geofisika, Wilayah II, Stasiun Klimatologi, Darmaga, Bogor.

\section{HASIL DAN PEMBAHASAN}

\section{Formulasi Ekstrak}

Formulasi ekstrak EC berbentuk cairan pekat yang homogen berwarna merah kecoklatan. Warna ini tidak jauh berbeda dengan warna bahan ekstrak sebelum dibuat formulasinya. Hasil pengujian kestabilan emulsi formulasi EC dari sediaan ekstrak metanol menunjukkan bahwa volume endapan setelah cairan semprot dibiarkan pada suhu $28{ }^{\circ} \mathrm{C}$ dan $10{ }^{\circ} \mathrm{C}$ selama 1 jam dan 2 jam tidak menunjukkan perbedaan (Tabel 2).

Tabel 2. Sifat fisikokimia formulasi EC sediaan kulit batang C. soulattri ${ }^{\mathrm{a}}$

\begin{tabular}{lcc}
\hline \multicolumn{1}{c}{ Sifat } & Suhu $28^{\circ} \mathrm{C}$ & Suhu $10^{\circ} \mathrm{C}$ \\
\hline Kestabilan emulsi & & \\
Setelah 1 jam & 0,45 & 0,45 \\
Volume endapan (ml) & 1,8 & 1,8 \\
Volume endapan (\%) & & - \\
Setelah 2 jam & 0,45 & - \\
Volume endapan (ml) & 1,8 & $7,2-7,3$ \\
Volume endapan (\%) & $7,2-7,3$ & Merah kecoklatan \\
PH & Merah kecoklatan & \\
Warna & &
\end{tabular}


Hal yang sama juga terjadi pada pengukuran $\mathrm{pH}$. Dengan tidak adanya perbedaan sifat fisikokimia formulasi ke dua sediaan tersebut maka dapat dikatakan formulasi EC tersebut stabil. Pada pengujian kestabilan emulsi terjadi pemisahan fase dengan pembentukan endapan pada dasar wadah. Persentase endapan yang terbentuk setelah dibiarkan selama 2 jam tidak lebih dari 2\%. Endapan yang terbentuk dari formulasi ekstrak 66 EC sebesar 1,8\%. Volume endapan dalam pengujian kestabilan emulsi yang disyaratkan dalam formulasi EC menurut spesifikasi WHO adalah tidak lebih dari $2 \mathrm{ml}$ dari $100 \mathrm{ml}$ emulsi yang diuji. Endapan yang terbentuk dari pengujian emulsi dari formulasi ekstrak 66 EC berbentuk padatan yang lengket, karenanya pada aplikasi sediaan tersebut diperlukan penyaringan endapan sebelum disemprotkan. Endapan yang terbentuk bila tidak disaring dapat menyumbat nozel alat semprot.

Keasaman $(\mathrm{pH})$ yang terukur dari formulasi berkisar antara 7,2-7,4. Dengan demikian sediaan formulasi bersifat normal. Formulasi EC dari ekstrak metanol daun $A$. odorata dan fraksi diklormetan-isopropanol (9:1) ranting $A$. odorata memiliki $\mathrm{pH}$ sediaan berkisar 5-5,5 (Syahputra, tidak dipublikasikan). Pada percobaan lain dilaporkan bahwa sediaan tersebut dapat menimbulkan gejala fitotoksik pada daun beberapa jenis bibit tanaman (Syahputra et al. 2007). Tampaknya terdapat hubungan antara pH sedian formulasi dengan gejala fitotoksisik yang ditimbulkan.

\section{Aktivitas Residu}

Hasil percobaan menunjukkan bahwa mortalitas larva uji menurun dengan semakin lamanya umur residu yang diuji (Tabel 3).

Tabel 3. Mortalitas larva $C$. pavonana instar akibat perlakuan residu formulasi sediaan ekstrak kulit batang C. Soulattri

\begin{tabular}{lcccccccc}
\hline \hline \multirow{2}{*}{\multicolumn{1}{c}{ Perlakuan }} & \multicolumn{6}{c}{ Rata-rata mortalitas (\%) larva instar II+III pada residu umur n hari $^{\text {a }}$} \\
\cline { 2 - 9 } & 0 & 1 & 2 & 3 & 5 & 7 & 10 & 14 \\
\hline Kontrol Ekstrak EC & 1,33 & 0 & 0 & 2,22 & 0 & 2,22 & 2,22 & 4 \\
Kontrol Ekstrak & & & & & & & & \\
EC+pAB & 0 & 0 & 2,22 & 0 & 1,33 & 1,11 & 3,33 & 2,67 \\
Ekstrak EC & 100 & 100 & 100 & 100 & 97,33 & 100 & 87,8 & 72 \\
Ekstrak EC+pAB & 100 & 100 & 100 & 100 & 90,67 & 92,2 & 82,2 & 70,7 \\
Bacillus thuringiensis & 100 & 100 & 100 & 100 & 100 & 98,9 & 83,3 & 45,3 \\
Profenofos & 100 & 100 & 100 & 100 & 100 & 97,8 & 58,9 & 10,7 \\
\hline
\end{tabular}


Penurunan mortalitas larva mulai tampak pada residu umur 5 hari setelah aplikasi. Pada umur residu tersebut sesama perlakuan formulasi ekstrak kulit batang C. soulattri dan formulasi insektisida sintetik belum menunjukkan perbedaan mortalitas yang mencolok. Pada umur residu tersebut semua perlakuan formulasi menyebabkan mortalitas yang tinggi yakni $>95 \%$.

Pada residu umur 7 hari, residu formulasi ekstrak tampak mulai mengalami penurunan aktivitas, namun nilainya masih $>90 \%$. Nilai aktivitas tersebut tidak berbeda dengan aktivitas residu perlakuan sediaan ekstrak dengan/tanpa tabir surya yang memiliki aktivitas $>90 \%$. Pada residu umur 10 hari mulai tampak penurunan aktivitas yang mencolok. Pada umur residu tersebut aktivitas insektisida sintetik sudah menurun hingga berada pada kisaran 58,9\%, sedangkan formulasi ekstrak aktivitasnya masih berada di sekitar 80\%-90\%.

Penurunan aktivitas residu terus terjadi dengan pola yang sama. Pada residu umur 14 hari tampak aktivitas residu insektisida alami dan sintetik turun mencolok, sedangkan aktivitas residu kedua perlakuan formulasi ekstrak terjadi penurunan yang tidak mencolok. Aktivitas residu formulasi insektisida profenofos dan Bacillus thuringiensis menurun hingga $<46 \%$. Ekstrak EC tanpa tabir surya menunjukkan aktivitas residu terbesar yakni $72 \%$, sedangkan ekstrak EC dengan tabir surya menjadi sebesar $70,7 \%$.

Penurunan mortalitas larva uji pada residu umur 7, 10, dan 14 hari semakin mencolok. Pola penurunan mortalitas larva uji setelah tanaman dipaparkan pada ruang terbuka disajikan pada Gambar 1. Penurunan mortalitas larva uji pada umur-umur residu tersebut disebabkan telah menurunnya senyawa aktif yang tertinggal pada residu formulasi pada daun perlakuan. Penurunan kandungan senyawa aktif ini dapat disebabkan oleh sinar matahari dan curah hujan selama percobaan. Di antara faktor abiotik tersebut yang penting adalah cahaya matahari. Cahaya matahari dapat menguraikan senyawa aktif insektisida menjadi senyawa lain yang biasanya kurang beracun dibandingkan senyawa induknya (Hassall 1990). Selama selang 15 hari percobaan dilakukan, intensitas penyinaran matahari tercatat pada kisaran 213-332 $\mathrm{k} / \mathrm{cm}^{2} /$ hari dengan rata-rata $292 \mathrm{k} / \mathrm{cm}^{2} /$ hari. Faktor tersebut mengakibatkan perubahan sifat kimia dan atau dapat mengurangi jumlah senyawa aktif yang akhirnya dapat menurunkan aktivitas residu.

Hasil perhitungan waktu paruh menunjukkan bahwa waktu paruh formulasi bervariasi (Tabel 4). Waktu paruh formulasi ekstrak hampir sama dengan formulasi insektisida Bacillus thuringiensis. Syahputra et al. (2007) 

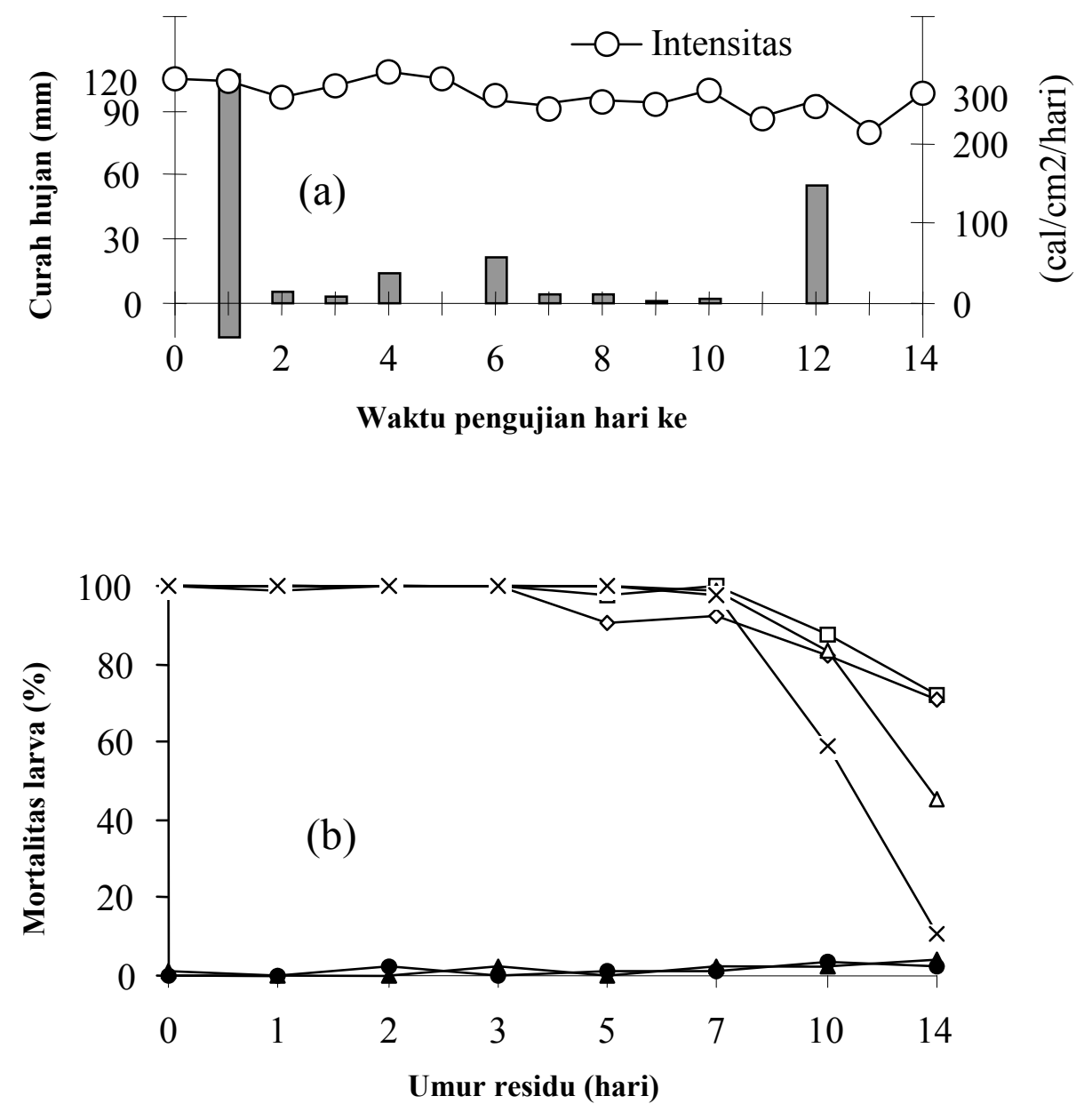

$\neg$ Kontrol Ekstrak EC

$\rightarrow$ Kontrol Ekstrak EC+pAB

$\neg \square$ Ekstrak EC

$\multimap$ Ekstrak EC+pAB

$\neg-$ Bacillus thuringiensis

$x$ Profenofos

Gambar 1. Aktivitas residu formulasi ekstrak kulit batang C. soulattri setelah dipaparkan di ruang terbuka, (a) curah hujan dan intensitas penyinaran selama pengujian, (b) mortalitas larva $C$. pavonana 
Tabel 4. Persamaan regresi dan waktu paruh formulasi ekstrak ${ }^{\mathrm{a}}$

\begin{tabular}{llc}
\hline \hline \multicolumn{1}{c}{ Formulasi } & Persamaan regresi ${ }^{\text {b }}$ & Waktu paruh (hari) \\
\hline Ekstrak EC & $Y=10,26-0,09 X$ & 9,6 \\
Ekstrak EC + pAB & $Y=10,21-0,12 X$ & 9,4 \\
Bacillus thuringiensis & $Y=10,55-0,20 X$ & 9,1 \\
Profenofos & $Y=11,12-0,43 X$ & 8,1 \\
\hline
\end{tabular}

${ }^{a}$ Konsentrasi cairan semprot yang digunakan $1 \%$.

b Persamaan regresi dihitung setelah data mortalitas ditransformasi ke $\sqrt{ }(y+0,5)$

melaporkan waktu paruh formulasi EC dan WP sediaan kulit batang $C$. soulattri berbahan fraksi diklorometana berkisar 6,7-8,2 hari. Hal ini menunjukkan bahwa senyawa aktif yang terdapat dalam formulasi ekstrak lebih sukar terurai dibandingkan dengan senyawa aktif yang terdapat dalam formulasi fraksi diklorometana. Dengan tingginya waktu paruh formulasi ekstrak tanpa tabir surya tampaknya penambahan tabir surya untuk formulasi ekstrak belum diperlukan. Hasil pengamatan fitotoksisitas pada percobaan ini menunjukkan bahwa tanaman brokoli yang diberi perlakuan formulasi EC sediaan ekstrak tidak menunjukkan gejala nekrosis pada tanaman.

\section{KESIMPULAN}

Emulsi formulasi EC dari sediaan ekstrak metanol pada suhu $28{ }^{\circ} \mathrm{C}$ dan $10{ }^{\circ} \mathrm{C}$ selama 1 jam dan 2 jam stabil. Persentase endapan yang terbentuk dari kedua formulasi yang dibuat setelah dibiarkan selama 2 jam tidak lebih dari $2 \%$. pH yang terukur dari kedua bahan formulasi berkisar antara
7,2-7,4. (normal). Pada residu umur 14 hari, aktivitas residu formulasi EC berbahan ekstrak tanpa atau dengan tabir surya masing-masing $72 \%$ dan $70,7 \%$ dengan waktu paruh masingmasing 9,56 hari dan 9,39 hari.

\section{SARAN}

Penelitian keefektifan sediaan ekstrak di lapangan dan kompatibilitas dengan parasitoid perlu dilakukan. Diperlukan juga analisis biaya produksi dalam pembuatan formulasi kulit batang C. soulattri.

\section{DAFTAR PUSTAKA}

[CIPAC] Collaborative International Pesticides Analytical Council. 1980. CIPAC. Handbook Analysis of Technical and Formulated Pesticides. New York: CIPAC.

Foy CL, Pritchard DW. 1996. Pesticide Formulation and Adjuvants Technology. New York: CRC Press.

Hassall KA. 1990. The Biochemistry and Uses of Pesticides: Structure, Metabolism, Mode of Action and Uses in Crop 
Protection, 2nd ed. London: Macmillan.

Immaraju J, Wells S, Ruggero W, Nelson R, Selby B. 1994.

Relative residual activities of azadirachtin,

dihydroazadirachtin and tetrahydroazadirachtin. Proc Brighton Crops Protection Conference.p 53-58.

Jacobson M. 2003. Insecticides, insect repellents and attractants from arid/semiarid-land plants. Di dalam: Plants: The Potentials for Extracting Protein, Medicines, and Other
Useful Chemicals. Workshop Proceedings.

http://www.wws.princeton.ed u/cgibin/byteserv.prl/ ota/dis k3/1983/8315/831511/pdf.

[25 Oktober 2003]. hlm 138146.

Syahputra E, Prijono D, Dono D. 2007. Sediaan Calophyllum soulattri: Aktivitas insektisida dan residu terhadap larva Crocidolomia pavonana dan keamanan pada tanaman. J.H.P.T. Trop. 7:21-29. 